\title{
Pengembangan Lembar Keria Siswa Berbasis Pendekatan Open-Ended untuk Melatih Kemampuan Pemecahan Masalah Matematis Siswa SMP
}

\author{
Lucy Asri Purwasi ${ }^{1}$ dan Nur Fitriyana ${ }^{2}$
}

1,2STKIP PGRI Lubuklinggau, Sumatera Selatan, Indonesia

Corresponding Author: asripurwasi@gmail.com

DOI: http://dx.doi.org/10.15294/kreano.v10i1.16825

Received: December 2019; Accepted: April 2019; Published: June 2019

\begin{abstract}
Abstrak
Penelitian ini bertujuan menghasilkan lembar kerja siswa berbasis pendekatan open-ended yang valid, praktis dan efektif untuk melatih kemampuan pemecahan masalah matematis siswa Kelas VIII SMP di Kota Lubuklinggau. Jenis penelitian yang dilakukan adalah penelitian pengembangan (Research and Development). Prosedur penelitian pengembangan LKS diadaptasi dari model pengembangan perangkat pembelajaran 4-D yang terdiri dari 4 tahap yaitu pendefinisian (define), perancangan (design), pengembangan (develop), dan penyebaran (disseminate). Ujicoba terbatas dan ujicoba kelompok besar dilakukan di SMP Negeri 14 Lubuklinggau kelas VIII dengan jumlah siswa sebanyak 29 orang. Berdasarkan hasil analisis data menghasilkan LKS berbasis pendekatan open-ended yang valid dengan nilai rata-rata 4,167, praktis dengan nilai rata-rata 4, 21 dan efektif dengan nilai rata-rata 4,126. Implementasi LKS Berbasis Pendekatan open-ended meningkatkan kemampuan pemecahan masalah siswa di SMP Negeri 1 Lubuklinggau sebesar 79,70\% dengan kategori baik, SMP Negeri 14 Kota Lubuklinggau sebesar 74,02\% dengan kategori baik, dan SMP PGRI 3 Kota Lubuklinggau sebesar 66,45\% dengan kategori baik.
\end{abstract}

\begin{abstract}
This study aims to produce mathematics student worksheets based on a valid, practical and effective openended approach in training mathematical problem solving skills of VIII SMP students in Lubuklinggau City. The type of research conducted is development research (Research and Development). The LKS development research procedure is adapted from a 4-D learning device development model consisting of 4 stages, namely define, design, develop, and disseminate. Limited trials and large group trials were conducted in the eighth grade Lubuklinggau Middle School 14 with a total of 29 students. Based on the results of data analysis produces worksheet based on a valid open-ended approach with an average value of 4.167, practically with an average value of 4.21 and effective with an average value of 4.126. Implementation of Student-Based Worksheets An open-ended approach improves students' problem solving abilities in Lubuklinggau Middle School 1 by $79.70 \%$ in good category, Lubuklinggau Middle School 14 State by $74.02 \%$ in good category, and Lubuklinggau City PGRI 3 Junior High School by $66.45 \%$ in good category.
\end{abstract}

Keywords: worksheet based on open-ended approach;problem solving ability. 


\section{PENDAHULUAN}

Matematika merupakan bagian dari disiplin ilmu yang memegang peranan penting dalam dunia pendidikan dan menghasilkan sumber daya manusia (SDM) yang kompeten. Dalam mempelajari matematika siswa diharapkan dapat menggunakan matematika dan pola pikir matematika dalam kehidupan seharihari, dapat mengembangkan daya nalar, dan membentuk sikap percaya diri serta mengembangkan keterampilan matematika. Menurut Sumarno (2014) kemampuan pemecahan masalah merupakan proses menemukan kembali (reinvetion) dalam memahami materi, konsep dan prinsip dalam menyelesaikan masalah, dimana karakteristik masalah bersifat tidak rutin, sehingga tergolong hard skill matematik tingkat tinggi. Isriani \& Puspitasari (2012) mengemukakan bahwa pemecahan masalah dipandang sebagai suatu proses untuk menemukan kombinasi dari sejumlah aturan yang dapat diterapkan dalam upaya mengatasi situasi yang baru. Pemecahan masalah tidak sekedar sebagai bentuk kemampuan menerapkan aturan-aturan yang telah dikuasai melalui kegiatan-kegiatan belajar terdahulu, melainkan lebih dari itu, merupakan proses untuk mendapatkan aturan pada tingkat yang lebih tinggi.

Kemampuan pemecahan masalah pada masing-masing siswa sangat penting untuk dilatih dan dikembangkan. Pentingnya kemampuan pemecahan masalah siswa ditandai dengan: 1) kemampuan menyelesaikan masalah merupakan tujuan umum dari pengajaran matematika, 2) penyelesaian masalah yang meliputi metode, prosedur dan strategi merupakan proses inti dan utama dalam kurikulum matematika, dan 3) penyelesaian masalah merupakan kemampuan dasar dalam belajar matematika (Branca, 1980). Hal ini juga ditegaskan oleh Hadi \& Radiyatul (2014) bahwa kemampuan menyelesaikan masalah merupakan tujuan umum pengajaran matematika, yang mengandung pengertian bahwa matematika dapat membantu dalam memecahkan persoalan baik dalam pelajaran lain maupun dalam kehidupan sehari-hari. Oleh karenanya kemampuan pemecahan masalah ini menjadi tujuan umum pembelajaran matematika.
Namun, kenyataan yang terjadi di lapangan terdapat faktor-faktor yang mempengaruhi keterampilan pemecahan masalah matematika sehingga menjadi hambatan dalam mengembangkannya. Misalnya, pembelajaran matematika selalu menjadi bidang studi yang kurang diminati sehingga kurangnya motivasi siswa dalam belajar matematika, proses pembelajaran matematika umumnya masih membiasakan siswa untuk mengerjakan latihan soal-soal rutin dan lebih banyak menghafal rumus, kecenderungan proses pembelajaran yang hanya mementingkan ketercapaian materi pembelajaran di kelas dan kurang tersedianya bahan ajar yang menfasilitasi siswa untuk dapat melatih keterampilan pemecahan masalah matematikanya.

Menurut Irawan et al (2016) selain pemilihan metode pembelajaran juga terdapat faktor internal lain yang mempengaruhi kemampuan pemecahan masalah matematika siswa seperti kemampuan pengetahuan awal, apresiasi siswa terhadap matematika, dan kecerdasan logis matematis. Sedangkan menurut Handayani (2017) faktor-faktor yang mempengaruhi kemampuan pemecahan masalah matematika yaitu: 1) pengalaman, 2) motivasi, 3) kemampuan memahami masalah dan 4) keterampilan berpikir. Berdasarkan kurikulum 2013, salah satu kompetensi yang harus dikembangkan dalam pembelajaran matematika di SMP adalah kemampuan berpikir. Pada jenjang SMP/MTs kemampuan berpikir siswa tergolong rendah, khususnya pada kompetensi pemecahan masalah open-ended (Rochmad et al, 2016).

Menurut Wahyudin (1999) di antara penyebab rendahnya pencapaian siswa dalam pelajaran matematika adalah proses pembelajaran yang belum optimal. Dalam proses pembelajaran umumnya guru sibuk sendiri menjelaskan apa-apa yang telah dipersiapkannya. Demikian juga siswa sibuk sendiri menjadi penerima informasi yang baik. Akibatnya siswa hanya mencontoh apa yang dikerjakan guru, tanpa makna dan pengertian sehingga dalam menyelesaikan soal siswa beranggapan cukup dikerjakan seperti apa yang dicontohkan. Hal tersebut menyebabkan siswa kurang memiliki kemampuan menyelesai- 
kan masalah dengan alternatif lain.

Berdasarkan hambatan dan rendahnya keterampilan pemecahan masalah matematis siswa hendaknya para guru harus lebih kreatif dan inovatif dalam memodifikasi pembelajaran yang dapat menjadikan siswa sebagai subjek belajar yang aktif, guru harus mampu mengembangkan bahan ajar yang sesuai dengan karakteristik atau kebutuhan siswa, mensetting kondisi kelas agar bisa menimbulkan rasa nyaman dan ketertarikan siswa sehingga optimalisasi pembelajaran di kelas dapat tercapai.

Keberhasilan proses pembelajaran matematika di kelas dapat dicapai secara optimal salah satunya melalui penggunaan bahan ajar yang mampu mengatasi kesulitan-kesulitan siswa dan sesuai dengan karakteristik atau kebutuhan siswa. Hal ini sejalan dengan pendapat Daryanto \& Dwicahyono (2014) yang mengemukakan bahwa guru harus memiliki atau menggunakan bahan ajar yang sesuai dengan kurikulum, karateristik sasaran, dan tuntunan pemecahan masalah belajar, sehingga kegiatan pembelajaran menjadi lebih menarik, siswa dapat belajar secara mandiri, dan memberikan kesempatan kepada siswa untuk menggali kompetensi yang dimilikinya. Sehingga Perlu dikembangkan bahan ajar yang salah satunya berupa lembar kerja siswa (LKS) yang memuat masalah-masalah terbuka (open-ended problems) dan langkah-langkah kerja untuk memecahkan masalah.

Trianto (2009) mendefinisikan bahwa lembar kerja siswa merupakan panduan siswa yang digunakan untuk melakukan kegiatan penyelidikan dan pemecahan masalah. Adapun karakteristik LKS, menurut Daryanto \& Dwicahyono (2014) yaitu, 1) berisi tugas yang harus dikerjakan oleh siswa, 2) berisi petunjuk, dan langkah-langkah kerja untuk menyelesaikan suatu tugas, 3) tugas-tugas yang diberikan kepada siswa dapat berupa teori atau praktik di lapangan.

Mavugara (2005) mengemukakan bahwa untuk memperkuat kemampuan siswa dalam pemecahan masalah, guru matematika perlu memanfaatkan masalah-masalah real yang bersifat open-ended yaitu masalah real yang mempunyai banyak cara menjawabnya atau banyak jawaban. Melalui masalah yang bersifat open-ended siswa berlatih menyelesaikan dengan caranya sendiri dan sekaligus berlatih memahami cara yang digunakan siswa lain. Dengan kegiatan ini diharapkan siswa dapat menjawab permasalah dengan banyak cara, sehingga mengundang potensi intelektual dan pengalaman siswa dalam proses menemukan sesuatu yang baru. Dengan demikian, pembelajaran matematika akan mengembangkan kemampuan pemecahan masalah matematis siswa (Yusuf et al, 2009)

Penggunaan lembar kerja siswa berbasis pendekatan open-ended dalam proses pembelajaran diharapkan dapat berpotensi dalam meningkatkan kualitas pembelajaran. $\mathrm{Hal}$ ini sejalan dengan pendapat Setiawan (2007) bahwa bahan ajar dianggap bahan yang dapat dimanfaatkan baik oleh guru maupun siswa dalam proses pembelajaran dan bertujuan untuk memperbaiki dan meningkatkan efektivitas pembelajaran siswa di kelas.

Berdasarkan hasil survey dan wawancara dengan guru matematika dan siswa kelas VIII Sekolah Menengah Pertama di Kota Lubuklinggau, diketahui bahwa masih terdapat masalah yang ditemui. Masih jarangnya guru melakukan pengembangan maupun penyusunan bahan ajar secara mandiri. Buku ajar maupun LKS yang gunakan dalam proses pembelajaran langsung diperoleh dari penerbit. LKS yang digunakan kurang memotivasi siswa untuk belajar, desainnya yang kurang menarik, tampilan LKS yang tidak berwarna, bahasa yang bersifat abstrak sehingga siswa sulit memahami isi LKS, tidak memuat kegiatan-kegiatan siswa karena guru menggunakan LKS ketika ingin memberikan soal latihan atau PR saja, lembar jawaban yang disediakan sangatlah sedikit sehingga siswa harus menuliskan jawaban di kertas lain dan tidak langsung menjabarkan jawaban di lembar jawaban yang disediakan dalam LKS. Di samping itu, tidak ada petunjuk penyajian dan langkah kerja LKS yang dapat mempermudah siswa memahami isi LKS. Selain itu juga, kesulitan guru dalam mengembangkan LKS sehingga siswa terbiasa menyelesaiam soal-soal masalah tertutup saja (closed problem) yang menuntut satu jawaban yang benar pada hasil akhirnya. Hal ini tentu bertentangan dengan 
tuntutan Kurikulum 2013 (K-13) bahwa pembelajaran tidak hanya menekankan pada hasil akhir saja tetapi proses juga harus dilihat.

Berdasarkan permasalahan di atas, maka perlu disusun dan dikembangkan lembar kerja siswa berbasis open-ended untuk melatih kemampuan pemecahan masalah matematis yang sesuai dengan tuntutan kurikulum dan karateristik siswa kelas VIII SMP di Kota Lubuklinggau. Tujuan penelitian adalah menghasilkan lembar kerja siswa matematika berbasis pendekatan open-ended yang valid, praktis dan efektif dalam melatih kemampuan pemecahan masalah matematis siswa Kelas VIII SMP di Kota Lubuklinggau.

\section{METODE}

Jenis penelitian yang dilakukan adalah penelitian pengembangan (Research and Develop- ment). Menurut Sugiyono (2011) metode penelitian dan pengembangan adalah metode penelitian yang digunakan untuk menghasilkan produk tertentu dan menguji keefektifan produk tersebut. Penelitian pengembangan ini dilaksanakan pada bulan Juli sampai dengan Agustus 2018 dan bertempat di SMP Kota Lubuklinggau. Terdapat 3 tempat penelitian baik SMP negeri maupun swasta yang berlokasi di Lubuklinggau.

Pemilihan sekolah dilakukan dengan mempertimbangkan tingkatan sekolah dengan kategori tinggi (A) dan sedang (B). Dari jumlah sekolah yang ada ditentukan tiga sekolah sebagai tempat penelitian, yaitu SMP Negeri 1 Lubuklinggau (A) yang berjumlah 33 orang siswa, SMP Negeri 14 Lubuklinggau (B) yang berjumlah 29 orang siswa dan SMP PGRI 3 Lubuklinggau (B) yang berjumlah 14 orang

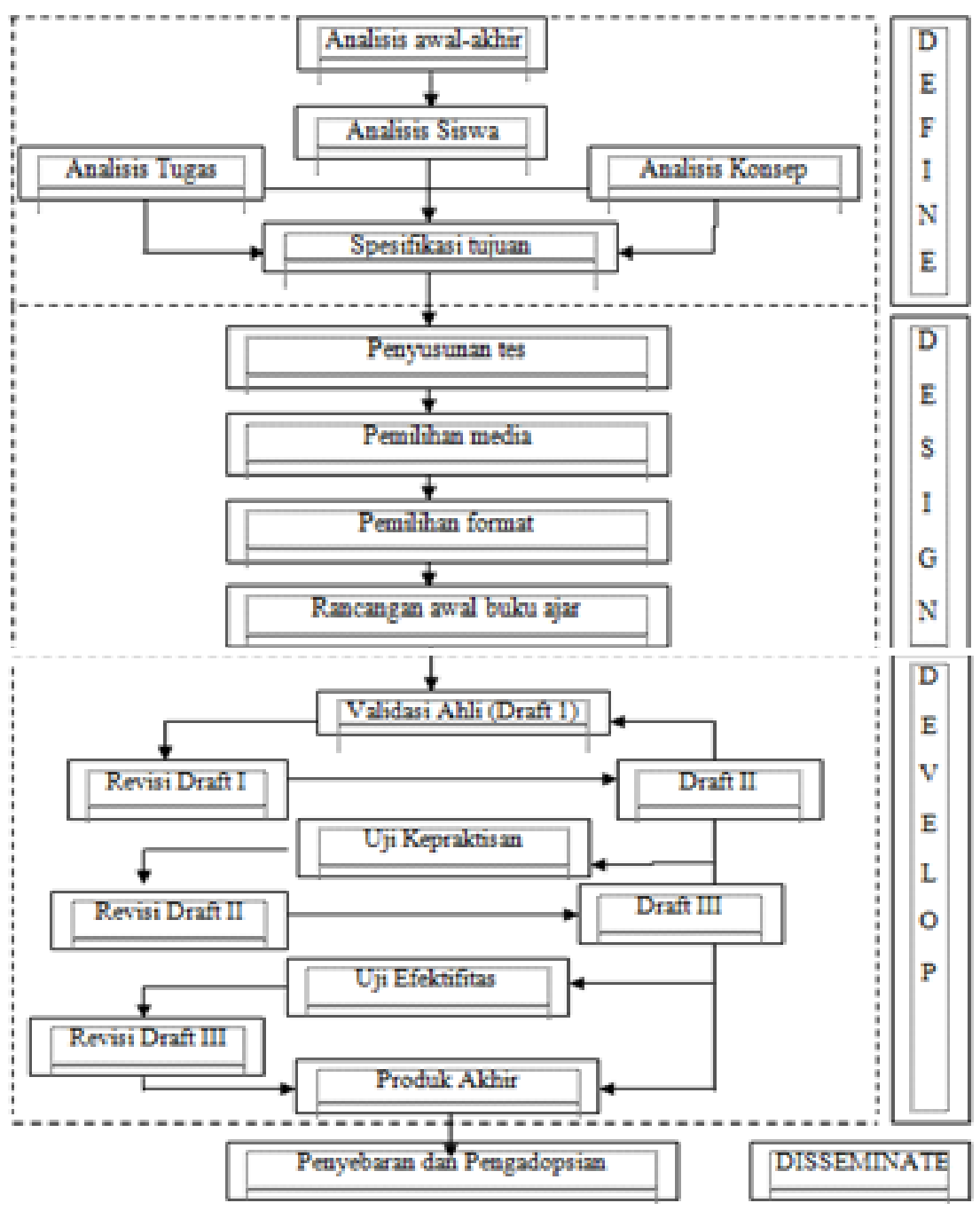

Gambar 1. Prosedur Pengembangan LKS berbasis pendekatan open-ended 
siswa.

Pengambilan sampel dilakukan secara stratefikasi random sampling, dimana setiap tingkatan sekolah ditentukan 1 kelas sebagai subjek penelitian. Ujicoba terbatas enam orang siswa dan ujicoba kelompok besar dilakukan di SMP Negeri 14 Lubuklinggau kelas VIII dengan jumlah siswa sebanyak 29 orang. Selanjutnya dilakukan uji efektivitas melalui implementasi LKS berbasis pendekatan openended ketiga sekolah.

Prosedur penelitian pengembangan LKS diadaptasi dari model pengembangan perangkat pembelajaran 4-D yang dikembangkan oleh Thiagarajan, Dorothy S. Semmel, dan Melvyn I (Trianto, 2009) yang secara umum terdiri dari 4 tahap yaitu pendefinisian (define), perancangan (design), pengembangan (develop), dan penyebaran (disseminate). Adapun prosedur penelitian pengembangan LKS berbasis pendekatan open-ended dapat dilihat pada Gambar 1.Adapun instrumen penelitian yang digunakan sebagai berikut.

\section{Lembar Validasi LKS Berbasis}

\section{Pendekatan Open-ended}

Instrumen ini digunakan untuk mendapatkan data mengenai pendapat para ahli (validator) terhadap LKS yang disusun pada rancangan awal. Lembar validasi LKS terdiri dari tiga lembar validasi yaitu, a) Lembar Validasi Materi, b) Lembar Validasi Konstruksi, dan c) Lembar Validasi Bahasa.

\section{Lembar Kepraktisan LKS Berbasis Pendekatan Open-ended}

Instrumen ini berupa angket yang diberikan kepada guru dan siswa sebagai pengguna produk LKS. Lembar ini berfungsi untuk mengetahui kepraktisan dari rancangan LKS yang telah valid.

\section{Tes Kemampuan Pemecahan Ma- salah}

Tes yang digunakan berjumlah 5 soal essay untuk mengukur tingkat kemampuan pemecahan masalah matematis siswa setelah men-

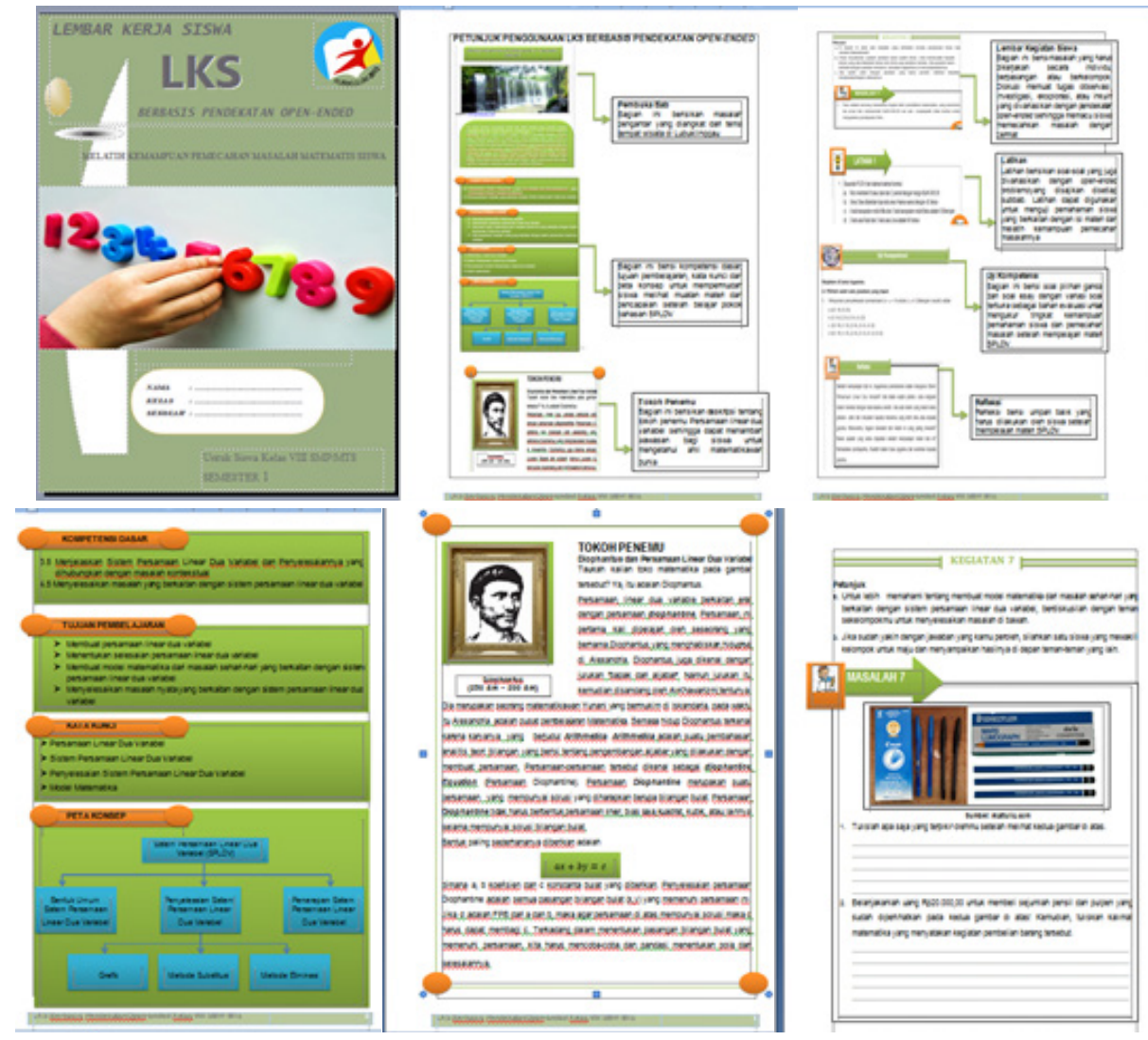

Gambar 2. Hasil Pengembangan LKS Berbasis pendekatan open-ended 
gikuti pembelajaran matematika menggunakan LKS berbasis pendekatan open-ended.

\section{Lembar Keefektifan LKS Matematika berbasis Pendekatan Open-ended}

Instrumen ini digunakan untuk memperoleh data tingkat keefektifan LKS yang dikembangkan, terdiri dari: a) Lembar Pengamatan Aktivitas Siswa dan Guru, b) Lembar Angket Respon Siswa, dan c) LembarTes Hasil Belajar.

\section{HASIL DAN PEMBAHASAN}

LKS yang dikembangkan adalah LKS berbasis pendekatan open-ended, di dalamnya berisi masalah terbuka yang akan diselesaikan siswa untuk membantu siswa dalam menemukan konsep SPLDV melalui pemecahan masalah matematis. Adapun karakteristik hasil bahan ajar (LKS) yang dikembangkan adalah sebagai berikut: 1) Halaman judul, 2) Petunjuk penggunaan LKS, 3) Pembuka Bab, 4) Pendahuluan yang berisi: kompetensi dasar, tujuan pembelajaran, kata kunci dan peta konsep, 4) Tokoh Penemu, 5) Panduan/ petunjuk untuk menyelesaikan masalah 6) Kegiatan yang berisikan masalah yang memuat investigasi, eksplorasi dan inkuiri yang divariasikan pendekatan open-ended sehingga memicu siswa memecahkan masalah dengan cermat, 7) Latihan yang berisikan soal-soal yang juga divariasikan dengan masalah-masalah terbuka, 8) Uji Kompetensi, 9) Refleksi.

Adapun pengembangan LKS berbasis pendekatan open-ended meliputi tahapan penilaian sebagai berikut.

\section{Uji Kevalidan}

Hasil uji validitas dari 3 orang validator dengan kualifikasi pendidikan untuk Validator pertama yaitu $\mathrm{S}_{3}$ Evaluasi Pendidikan, Validator kedua yaitu S3 Teknologi Pendidikan dan Validator ketiga guru besar pendidikan matematika UNIB.

Berdasarkan data penilaian hasil validasi materi yang terdiri atas pertanyaan-pertanyaan sebagai berkut: LKS sesuai dengan tujuan yaitu memecahkan masalah melalui open-ended problems; LKS sesuai dengan tujuan yaitu memudahkan siswa untuk memahami materi yang disajikan; LKS sesuai dengan struktur LKS; LKS disusun berdasarkan ciri khas atau karakteristik pendekatan open-ended, yaitu suatu pendekatan yang menyajikan permasalahan yang memiliki variasi jawaban benar baik itu dari metode maupun penyelesaiannya; Menggunakan kalimat yang sederhana, jelas dan mudah dimengerti; Alur pembelajaran jelas sehingga siswa dapat menemukan konsep secara terarah; Keserasian antara ukuran huruf, jenis huruf, ukuran gambar dan warna gambar; Menyediakan ruangan yang cukup untuk siswa menulis; Menggunakan tulisan atau penomoran yang membedakan sub-sub judul maupun soal secara jelas; Penampilan LKS menarik yaitu adanya kombinasi antara huruf, gambar dan warna yang sesuai; Langkah-langkah pada LKS membimbing siswa memecahkan masalah terbuka (open-ended problems) serta memahami suatu konsep, hasil analisis kevalidan materi tiga orang validator ahli materi menunjukkan bahwa LKS berdasarkan materi dinilai dengan skor rata-rata 4,125 yaitu dengan kriteria "sangat valid". (data real silakan hubungi author: Red)

\section{Validasi Kontruksi/Media}

Adapun hasil validasi kontruksi/ media dari ketiga validator dengan item pertanyaan LKS disusun berdasarkan ciri khas atau karakteristik pendekatan open-ended, yaitu suatu pendekatan yang menyajikan permasalahan yang memiliki variasi jawaban benar baik itu dari metode maupun penyelesaiannya; Penampilan LKS menarik yaitu adanya kombinasi antara huruf, gambar dan warna yang sesuai; Langkah-langkah pada LKS membimbing siswa memecahkan masalah terbuka (open-ended problems) serta memahami suatu konsep; hasil validasi kontruksi/media yang dilakukan oleh tiga orang validator menunjukkan bahwa LKS berdasarkan pada kontruksi/media dinilai dengan skor rata-rata 4,185 yaitu dengan kriteria "sangat valid". (data real silakan hubungi author: Red)

\section{Validasi Bahasa}

Adapun hasil validasi bahasa dari ketiga validator dapat dilihat pada tabel 1 berikut. 
Tabel 1. Penilaian Hasil Validasi Media

\begin{tabular}{|c|c|c|c|c|c|c|}
\hline \multirow{2}{*}{ Pertanyaan } & \multicolumn{3}{|c|}{ Skor } & & & \multirow{2}{*}{ Kriteria } \\
\hline & $V_{1}$ & $\mathrm{~V}_{2}$ & $V_{3}$ & & & \\
\hline Tulisan pada LKS terlihat dengan jelas & 4 & 4 & 4 & 12 & 4 & Sesuai \\
\hline Tulisan pada LKS menggunakan huruf yang mudah dibaca & 4 & 5 & 4 & 13 & 4,33 & Sesuai \\
\hline $\begin{array}{l}\text { LKS menggunakan bahasa sesuai dengan tingkat pemikiran } \\
\text { siswa }\end{array}$ & 5 & 4 & 5 & 14 & 4,67 & $\begin{array}{l}\text { Sangat } \\
\text { Sesuai }\end{array}$ \\
\hline $\begin{array}{l}\text { LKS ini menggunakan kalimat yang sederhana, jelas dan } \\
\text { mudah dipahami }\end{array}$ & 4 & 4 & 4 & 12 & 4 & Sesuai \\
\hline $\begin{array}{l}\text { Aturan penulisan LKS sesuai dengan aturan bahasa yang } \\
\text { baik }\end{array}$ & 4 & 4 & 4 & 12 & 4 & Sesuai \\
\hline $\begin{array}{l}\text { Gambar pada LKS sesuai dengan tujuan LKS dan dapat } \\
\text { dilihat dengan jelas }\end{array}$ & 4 & 4 & 4 & 12 & 4 & Sesuai \\
\hline Total & 25 & 25 & 25 & & & \\
\hline Rata-rata & & & 4,167 & & & $\begin{array}{l}\text { Sangat } \\
\text { Valid }\end{array}$ \\
\hline
\end{tabular}

Berdasarkan tabel 1 , analisis kevalidan berdasarkan data penilaian hasil validasi oleh uji ahli bahasa yang dilakukan oleh tiga orang validator menunjukkan bahwa LKS berdasarkan bahasa dinilai dengan skor rata-rata 4,167 yaitu dengan kriteria "sangat valid".

Hasil validasi dari ketiga bagian yaitu materi, konstruksi dan bahasa secara umum diperoleh skor 4,1 . Skor tersebut menghasilkan nilai "sangat valid" berdasarkan kriteria yang telah dibuat. Ini berarti LKS sudah layak digunakan sebagai bahan ajar penunjang baik dari segi materi, media/konstruksi, dan bahasa. Setelah dilakukan uji validitas menghasilkan draft II LKS berbasis pendekatan openended.

\section{Uji Kepraktisan LKS Berbasis Pendekatan Open-ended}

Uji kepraktisan dilakukan untuk mengetahui apakah bagian-bagian dalam LKS praktis dan mudah digunakan oleh siswa dan guru sebagai pengguna.Uji kepraktisan dilakukan terhadap enam siswa dan guru matematika kelas VIII di SMP Negeri 14 Lubuklinggau. Analisis kepraktisan berdasarkan data penilaian lembar kepraktisan oleh siswa dan guru menunjukkan bahwa draf II LKS yang diuji kepraktisannya menghasilkan skor rata-rata 4, 21 yaitu dengak kriteria "Sangat Praktis" dan rata-rata 4 yaitu dengan kriteria sangat praktis"berdasarkan kriteria yang telah dibuat. Hasil ini menunjukan bahwa bagian-bagian pada LKS siswa dan guru sangat dapat digunakan dengan baik tanpa ada kendala yang berarti. LKS yang telah diuji kepraktisan dengan menghasilkan darft III dapat digunakan dalam proses pembelajaran yang sesungguhnya.

\section{Uji Keefektifan LKS Berbasis Pendekatan Open-ended}

Uji keefektifan dilakukan setelah proses uji kepraktisan menghasilkan draft III LKS yang valid dan praktis. LKS diujicobakan terhadap 29 siswa kelas VIII SMP Negeri 14 Lubuklinggau. Pada uji keefektifan ini dilakukan analisis data aktivitas dalam proses belajar mengajar yang terdiri dari aktivitas siswa dan aktivitas guru, analisis respon siswa terhadap LKS, dan hasil belajar siswa setelah proses pembelajaran.

\section{Analisis Aktivitas Siswa dan Guru dalam menggunakan LKS}

Menurut Sardiman (2007) aktivitas belajar sangat diperlukan dalam proses pembelajaran karena pada prinsipnya belajar adalah berbuat, berbuat untuk mengubah tingkah laku, dan melakukan kegiatan.

Jumlah skor rata-rata aktivitas diperoleh dengan menjumlahkan rata-rata skor aktivitas siswa dan guru dibagi dua, sehingga diperoleh jumlah rata-rata 4,21. Sedangkan jumlah rata- rata aktivitas siswa dan guru masing-masing diperoleh 4,05 dan 4,375. 


\section{Analisis Respon Siswa}

Angket respon siswa dalam penelitian ini berupa tanggapan peserta didik setelah mengikuti pembelajaran dengan menggunakan lembar kerja siswa berbasis pendekatan open-ended. Skor rata-rata respon siswa diperoleh adalah 4,21.

\section{Analisis Tes Hasil Belajar}

Data hasil belajar siswa selama proses pembelajaran diperoleh melalui tes hasil belajar setelah berakhirnya proses pembelajaran. Skor rata-rata hasil belajar siswa diperoleh dengan menjumlahkan skor hasil belajar per siswa, kemudian dibagi banyaknya siswa. Skor rata-rata hasil belajar siswa adalah 4 .

Hasil penelitian menunjukkan bahwa 23 siswa tuntas secara individual. Selain itu siswa juga memenuhi kriteria ketuntasan secara klasikal, karena persentase jumlah siswa yang tuntas sebesar 79,3\%, sehingga dapat dikatakan bahwa secara keseluruhan siswa telah mencapai kompetensi yang telah ditentukan. Hasil uji keefektifan memberikan nilai 4,126.

Berdasarkan analisis data yang diperoleh terlihat bahwa keefektifan LKS siswa dan guru dalam kategori "sangat efektif". Hal ini menunjukkan LKS berbasis pendekatan openended sangat layak digunakan dan memberikan manfaat pada proses pembelajaran yakni mengefektifkan aktivitas dalam kegiatan belajar mengajar, respon dan hasil belajar siswa. Hal ini sejalan dengan penelitian Evalida \& Hastarudin (2016) hasil analisis keefektifan pembelajaran dengan LKS berbasis open ended yang telah ditetapkan menghasilkan: (1) ketuntasan klasikal hasil belajar siswa menunjukkan pembelajaran dengan lembar kerja siswa berbasis pendekatan open-ended di kelas VIII-1 sudah mencapai kriteria ketuntasan; (2) ketercapaian indikator sudah tercapai; (3) respon siswa terhadap pembelajaran dengan lembar kerja siswa berbasis pendekatan openended adalah positif.

Dari hasil keseluruhan analisis data diproleh produk akhir LKS yang valid, praktis dan efektif. Untuk menentukan kualitas LKS hasil pengembangan, diperlukan tiga kriteria penilaian yang mengacu pada pendapat Nieveen (1999) dan Akker (1999). Ketiga kriteria yang dimaksudkan yaitu: penilaian kevalidan, kepraktisan, dan keefektifan.

Sehingga ketika sudah memenuhi ketiga kriteria ini LKS berbasis pendekatan openended dapat diimplementasikan ketiga sekolah yaitu, SMP Negeri 1 Lubuklinggau, SMP Negeri 14 Kota Lubuklinggau dan SMP PGRI 3 Kota Lubuklinggau untuk mengoptimalkan kemampuan pemecahan masalah matematis siswa melalui penyajian soal-soal terbuka pada setiap tahapan kegiatan yang disajikan. Berdasarkan penelitian yang dilakukan oleh Mayasari (2014) menunjukkan bahwa bahan ajar yang dikembangkan berbasis open ended efektif untuk meningkatkan kemampuan pemecahan matematika dengan validasi sebesar 4,15 .

Selanjutnya berdasarkan penelitian yang dilakukan Evalida \& Hastarudin (2016) yaitu LKS yang dikembangkan berbasis pendekatan open-ended dalam meningkatkan kemampuan pemecahan masalah matematika dan berpikir kreatif siswa tercapai setelah dua kali ujicoba. Pada ujicoba I, ketuntasan klasikal sebesar 63,15\%. Pada ujicoba II, ketuntasan siswa secara klasikal sebesar $87,5 \%$ dan ketercapaian indikator tuntas.

Adapun persentase rata-rata hasil akhir kemampuan pemecahan masalah matematis SMP Negeri 1 Kota Lubuklinggau sebesar 79,70\% dengan kategori baik, SMP Negeri 14 Kota Lubuklinggau sebesar 74,02 dengan kategori baik, dan SMP PGRI 3 Lubuklinggau sebesar $66,45 \%$ dengan kategori baik.

\section{SIMPULAN}

Adapun kesimpulan dari penelitian ini adalah 1) Pengembangan LKS dengan pendekatan Open Ended pada materi SPLDV untuk siswa kelas VIII dilakukan dengan mengadopsi model pengembangan 4-D (four D model). Model ini terdiri dari 4 tahap pengembangan, yaitu Define, Design, Develop, and Disseminate. Proses pada tahap Define meliputi: a) analisis awal, b) analisis siswa, c) analisis tugas, d) analisis konsep, dan e) merumuskan tujuan pembelajaran. Proses pada tahap Design meliputi: a) tes acuan patokan, b) pemilihan media, c) pemilihan format dan d) desain awal LKS. Proses pada tahap Develop meliputi: a) validasi oleh para ahli diikuti dengan revisi, b) uji coba produk kelompok terbatas dan ke- 
lompok besar. Proses pada tahap Disseminate dengan melakukan penyebaran LKS pada sekolah lainnya. Sehingga dengan tahapan ini menghasilkan LKS berbasis pendekatan open-ended yang valid dengan nilai rata-rata keseluruhan 4,167 , praktis dengan nilai ratarata keseluruhan 4,21 dan efektif dengan nilai rata-rata keseluruhan 4,$126 ; 2$ ) Implementasi LKS berbasis pendekatan open-ended dapat meningkatkan kemampuan pemecahan masalah siswa melalui kegiatan yang menyajikan masalah-masalah terbuka sehingga siswa dapat aktif, kreatif dan lebih terlatih dalam menyelesaikan masalah pada LKS. LKS berbasis pendekatan open-ended dapat meningkatkan kemampuan pemecahan masalah siswa di SMP Negeri 1 Lubuklinggau sebesar 79,70\% dengan kategori baik, SMP Negeri 14 Kota Lubuklinggau sebesar $74,02 \%$ dengan kategori baik, dan SMP PGRI 3 Kota Lubuklinggau sebesar $66,45 \%$ dengan kategori baik.

\section{DAFTAR PUSTAKA}

Akker, J. Van den. (1999). Principles and Method of Development Research. London. DIm. van den Akker, J., Branch, R.M., Gustafson, K., Nieveen, N., \& Plomp, T. (pnyt.)". Design approaches and tools in educational and training. Dordrecht: Kluwer Academic Publisher.

Branca, N.A. (1980). Problem Solving as a Goal, Process, and Basic Skill. Problem Solving in School Mathematics. Editor: Krulik, S. and Reys, R.E. Reston: National Council of Teachers of Mathematics.

Daryanto \& Dwicahyono, A. (2014). Pengembangan Perangkat Pembelajaran (Silabus, RPP, PHB, Bahan Ajar). Yogyakarta: Gava Media.

Evalida, A., \& Hasratuddin. (2016). Pengembangan Lembar Kerja Siswa Berbasis Pendekatan Open-Ended untuk Meningkatkan Kemampuan Pemecahan Masalah Matematika dan Berpikir Kreatif Siswa Kelas VIII SMP Berastagi T.A. 2014/2015 Jurnal Inspiratif, 2, 9-19.

Hadi, S., \& Radiyatul. (2014). Metode Pemecahan Menurut Polya Untuk Mengembangkan Kemampuan Siswa Dalam Pemecahan Mateamatis Di Sekolah Menengah Pertama. EDU-MAT Jurnal Pendidikan Matematika , 2, 53-61.

Handayani, K. (2017). Analisis Faktor - Faktor Yang
Mempengaruhi Kemampuan Pemecahan Masalah Soal Cerita Matematika. Seminar Nasional Matematika: Peran Alumni Matematika dalam Membangun Jejaring Kerja dan Peningkatan Kualitas Pendidikan (pp. 325-330). Medan: Fakultas Matematika Universitas Negeri Medan.

Irawan, I. P., Suharta, I. G., \& Suparta, I. N. (2016). Faktor-Faktor yang Mempengaruhi Kemampuan Pemecahan Masalah Matematika: Pengetahuan Awal, Apresiasi Matematika dan Kecerdasan Logis Matematis. Prosiding Seminar Nasional MIPA (pp. 69-73). Denpasar: FMIPA Undiksha .

Isriani, H., \& Puspitasari, D. (2012). Strategi Pembelajaran Terpadu (Teori, Konsep, dan Implementasi). Yogyakarta: Familia.

Mavugara, S. (2005). Teaching for Mathematical Literacy in Secondary and High Schools in Lesotho: A Didactic Perspective. Dissertation of The University of The Free State, Bloemfontein.

Mayasari, D. (2014). Pengembangan Bahan Ajar dengan Menggunakan Pendekatan Open Ended untuk Meningkatkan Kemampuan Pemecahan Masalah Matematis Siswa SMP Negeri 6 Pematangsiantar. Tesis Program Pascasarjana. Universitas Negeri Medan.

Nieveen, Ninke. et al. (1999) . Design Approaches and Tools in Education and Training. Dordrecht: Kluwer Academic Publishers.

Rochmad, Agoestanto, A., \& Kurniasih, A. W. (2016). Analisis Time-Line dan Berpikir Kritis dalam Pemecahan Masalah Matematika pada Pembelajaran Kooperatif Resiprokal . Jurnal Matematika Kreatif-Inovatif, 217-231.

Setiawan, D. (2007). Pengembangan Bahan Ajar. Jakarta: Universitas Terbuka

Sumarno, U. (2014). Asesmen Soft Skill dan Hard Skill Matematik Siswa Dalam Kurikulum 2013. Seminar Pendidikan Matematika (pp. 1-30). Padang: Sekolah Tinggi Agama Islam Negeri Batu Sangkar.

Trianto. (2009). Mendesain model pembelajaran inovatifprogresif konsep, landasan dan implementasi pada kurikulum tingkat satuan pendidikan (KTSP). Jakarta: Kencana

Wahyudin. (1999). Kemampuan Guru Matematika, Calon Guru Matematik, dan Siswa dalam Mata Pelajaran Matematika. Disertasi PPS. IKIP Bandung.

Yusuf, M., Zulkardi \& Saleh, T. (2009). Pengembangan Soal-Soal Open-Ended Pada Pokok Bahasan Segitiga Dan Segiempat Di SMP. Jurnal pendidikan Matematika UNSRI, 2, 48-56. 